\title{
SEBARAN KONSENTRASI COLIFORM DAN ESCHERICHIA COLI PADA AIR TANAH DANGKAL KOTA GORONTALO
}

\author{
Marike Mahmud $^{\mathrm{a}}$ \\ ${ }^{a}$ Fakultas Teknik, Universitas Negeri Gorontalo, Jl. Prof. Dr. Ing.B.J. Habibie, Gorontalo, Indonesia
}

\section{ARTICLE INFO}

\section{Article history:}

Received: 6 December 2020

Accepted: 18 January 2021

Published: 25 January 2021

\section{Keywords:}

Bacteria; Quality Standard; Spatial; Water Pollution

\section{Corresponding author:}

Marike Mahmud

Fakultas Teknik, Universitas Negeri

Gorontalo, Gorontalo, Indonesia

Email: marikemahmud@ung.ac.id

\begin{abstract}
This study aims to analyze the spatial distribution of coliform and E. coli in groundwater Gorontalo City and the factors that influence it. The sampling locations were taken from 9 sub-districts consisting of 27 villages. The nine subdistricts consist of Dumbo Raya, Hulondalangi Kota Barat, Kota Utara, Kota Timur, Kota Selatan, Sipatana, Dungingi, and Padebuolo Districts. Sampling in each village consisted of 1 sample and was taken randomly. Kota Utara Subdistrict consisted of 1 sample location, namely Dembe Jaya Village. Kota Timur Sub-district consists of 2 villages, namely Padebuolo and Heledulaan Selatan villages. Kota Selatan sub-district consists of Limba U 1. Kota Tengah sub-district consists of Liluwo Village. The Sipatana sub-district consists of Tanggikiki, Bulotadaa, and Tapa Villages. Dungingi sub-district consists of Tulandenggi and Libuo Villages. The total number of samples was 27 . The analysis was carried out at the Gorontalo District Health Office, UPTD of Water Quality Laboratory Installation. The sampling method was carried out aseptically. Measurements in the laboratory used the MPN method. The quality standard that became the reference was Permenkes (Health Minister Regulation) number 32 of 2017 Annex 1 regarding water for sanitation and hygiene. The results of the analysis showed that the distribution of the number of coliform bacteria, in general, was at the quality standard set. A total of 24 villages of 27 locations were above the established quality standard. Regarding the number of E. coli bacteria from 27 locations, there were 5 locations above the established quality standards. The factor that affected the pollution was the distance of the septic tank which was very close to the well (water source).
\end{abstract}

Copyright (C) 2021 The Authors This open access article is distributed under $a$ Creative Commons Attribution (CC-BY) 4.0 International license

\section{Pendahuluan}

Mutu dari kelayakan sumur gali sebagai sumber air baku, air minum dan air bersih perlu menjadi perhatian masyarakat. Sumur gali merupakan air tanah dangkal karena sumber airnya dekat dengan permukaan tanah. Hal ini menyebabkan air sumur mudah terkontaminasi oleh bakteri-bakteri yang berada di sekitarnya. Sumber pencemaran dapat berasal dari rembesan air kotor dari limbah domestik, sampah juga kotoran hewan maupun manusia. Salah satu penyebab diare dapat diketahui dari tercemarnya air sumur oleh bakteri. Air yang mengandung bakteri pathogen dapat menyebabkan berbagai penyakit seperti disentri, tipus, dan kolera (Kuswiyanto, 2015). Sebagaimana laporan BPS (2019), bahwa pada tahun 2019, jumlah kasus diare di Provinsi Gorontalo adalah 32.471 jiwa dan balita 19.086 jiwa. Sebanyak $4.29 \%$ kasus diare, jika dibandingkan dengan jumlah penduduk Provinsi Gorontalo 1.202.631 (BPS, 2019). Oleh karena itu, kelayakan sumur gali untuk keperluan hygiene sanitasi harus sesuai dengan standar baku mutu sebagaimana diatur dalam Peraturan Menteri Kesehatan (PMK) 32 Tahun 2017.

Air tanah mengandung zat-zat organik maupun non-organik sehingga merupakan tempat yang baik bagi pertumbuhan mikroorganisme. Salah satu faktor yang menentukan populasi mikroorganisme dalam air adalah temperatur. Temperatur sekitar $30^{\circ} \mathrm{C}$, kurang baik untuk pertumbuhan bakteri 
pathogen yang berasal dari hewan maupun manusia. Terdapat 3 jenis bakteri yang berkaitan dengan sanitasi lingkungan. Bakteri tersebut meliputi Escherichia coli, kelompok Streptococcus fecal dan Clostridium perfringens. Jenis E. coli merupakan indikator yang paling banyak digunakan. E. coli merupakan bakteri komensal yang hidup pada usus manusia. Adanya E. coli dalam air atau makanan dapat membahayakan kesehatan manusia (Kuswiyanto, 2016). Pengawasan untuk mikrobiologi pathogen secara tradisional melibatkan indikator organisme. Organisasi kesehatan dunia (WHO) merekomendasikan E. coli sebagai parameter penting dari pemantauan air minum (Invik et al., 2017). Masyarakat yang tinggal di pedesaaan, sering menggunakan air tanah yang tanpa diolah sebagai sumber air minum. Hal ini berpotensi memiliki risiko lebih besar tertular penyakit melalui air, jika dibandingkan masyarakat di perkotaan (Galanis et al., 2014).

Escherichia coli merupakan bagian dari mikroorganisme yang normal pada usus besar manusia dan binatang. Dapat menjadi pathogen pada manusia baik di dalam maupun di luar saluran cerna. Kebanyakan galur bakteri ini, menfermentasikan lactose berbeda, dengan bakteri pathogen lainnya. E. coli memiliki banyak sifat yang serupa dengan Enterobacteriaceae lainnya. Penularan penyakit usus umumnya bisa terjadi melalui jalur fecal-oral dengan makanan dan air yang tercemar sebagai media penularan. Pada dasarnya semua E. coli adalah organisme yang sama, hanya berbeda pada jejak patogenik spesifik. Harus dicurigai adanya infeksi oleh E. coli EHEC pada semua pasien yang menderita diare akut berdarah, terutama jika berhubungan dengan nyeri pada perut dan tidak adanya demam. Penyakit usus ini paling baik dicegah dengan berhati-hati dalam memilih, menyiapkan dan mengkonsumsi makanan dan air (Cornelissen et al., 2015). Sejumlah bakteri E. coli dapat menimbulkan sakit perut ringan sampai berat dengan beberapa infeksi berbeda. Bakteri E. coli strain O 157:H7 sering disebut juga bakteri Enterohaemorragic Esherichia Coli (EHEC). Timbulnya gejala diare, kram perut, demam, serta muntah darah perlu diwaspadai sebagai gejala penyakit yang disebabkan oleh bakteri virulen ini. Bakteri ini ditularkan melalui produk hewan dan sayuran mentah yang tidak dicuci (Kuswiyanto, 2015). Penelitian yang dilakukan oleh Putri \& Kurnia (2018) menunjukkan bahwa pada air sumur bor di Bukit Tinggi yang dekat dengan sumber pencemaran tinggi telah tercemar dengan bakteri, dimana Sampel A sebesar 150/100 ml dan sampel B dan C di atas 2400/100ml. Hal ini perlu perhatian oleh masyarakat, ketika menggunakan air sumur baik sebagai sumber air baku, air minum maupun sebagai sumber air bersih. Pentingnya penelitian ini untuk mengobservasi dan menganalisis sumber air tanah dangkal yang tersebar di Kota Gorontalo sehingga dapat dicegah pencemarannya.

Penelitian yang dilakukan oleh Putra (2018) menunjukkan bahwa sebanyak 30 sumur gali pada masyarakat di Dusun Nanas Kabupaten Kediri, memenuhi syarat kualitas fisik, dan 28 memenuhi kualitas mikrobiologi. Penelitian uji bakteri oleh Irdawati et al., (2012), di lokasi pemukiman penduduk sekitar Tempat Pembuangan Akhir (TPA) sampah, menunjukkan terdapat 9 sumur mengandung cemaran coliform dan E. coli dan tidak layak dikonsumsi. Hal ini akan membahayakan kesehatan masyarakat. Salah satu penyebab diare dapat diketahui dari tercemarnya air sumur oleh coliform. Posisi sumur yang dekat dengan TPA dikhawatirkan akan berdampak langsung dengan mikroorganisne dan mikroba pathogen yang akan berkembang yang salah satunya adalah coliform. Pada penelitian ini juga ingin mengetahui kondisi lingkungan sekitar yang mempengaruhi coliform. Hasil penelitian yang dilakukan oleh Awuy et al., (2018) menunjukkan bahwa semua sumur yang berada Kelurahan RapRap Kecamatan Airmadidi Kabupaten Minahasa Utara mengandung E. coli. Perlu upaya perbaikan konstruksi sumur. Adanya fecal coliform di dalam air sumur dapat memberi petunjuk bahwa air tanah telah terkontaminasi oleh bakteri, virus atau organisme penyakit lannya. Air yang terkontaminasi organisme bakteri dapat menyebabkan penyakit. Berbagai penyakit yang disebabkan oleh bakteri ini maka dikhawatirkan akan terjadi di Kota Gorontalo. Penelitian ini bertujuan untuk menganalisis sebaran bakteri coliform dan E. coli pada air tanah di Kota Gorontalo dan faktor-faktor yang mempengaruhinya.

\section{Metode}

\subsection{Lokasi Penelitian}

Pengambilan sampel air tanah di Kota Gorontalo dilakukan secara acak pada tiap kelurahan. Dasar pengambilan sampel adalah air tanah tersebut digunakan sehari-hari sebagai sumber air bersih oleh masyarakat. Wawancara juga dilakukan pada masyarakat yang air tanahnya dijadikan sebagai sampel. Lokasi pengambilan sampel dilakukan di 9 kecamatan. Tiga dari kecamatan tersebut adalah Kecamatan Dumbo Raya, Hulondalangi dan Kota Barat masing-masing diambil 1 sampel setiap kelurahan. Enam kecamatan lainnya diambil secara acak. Kecamatan Kota Utara 1 sampel yakni 


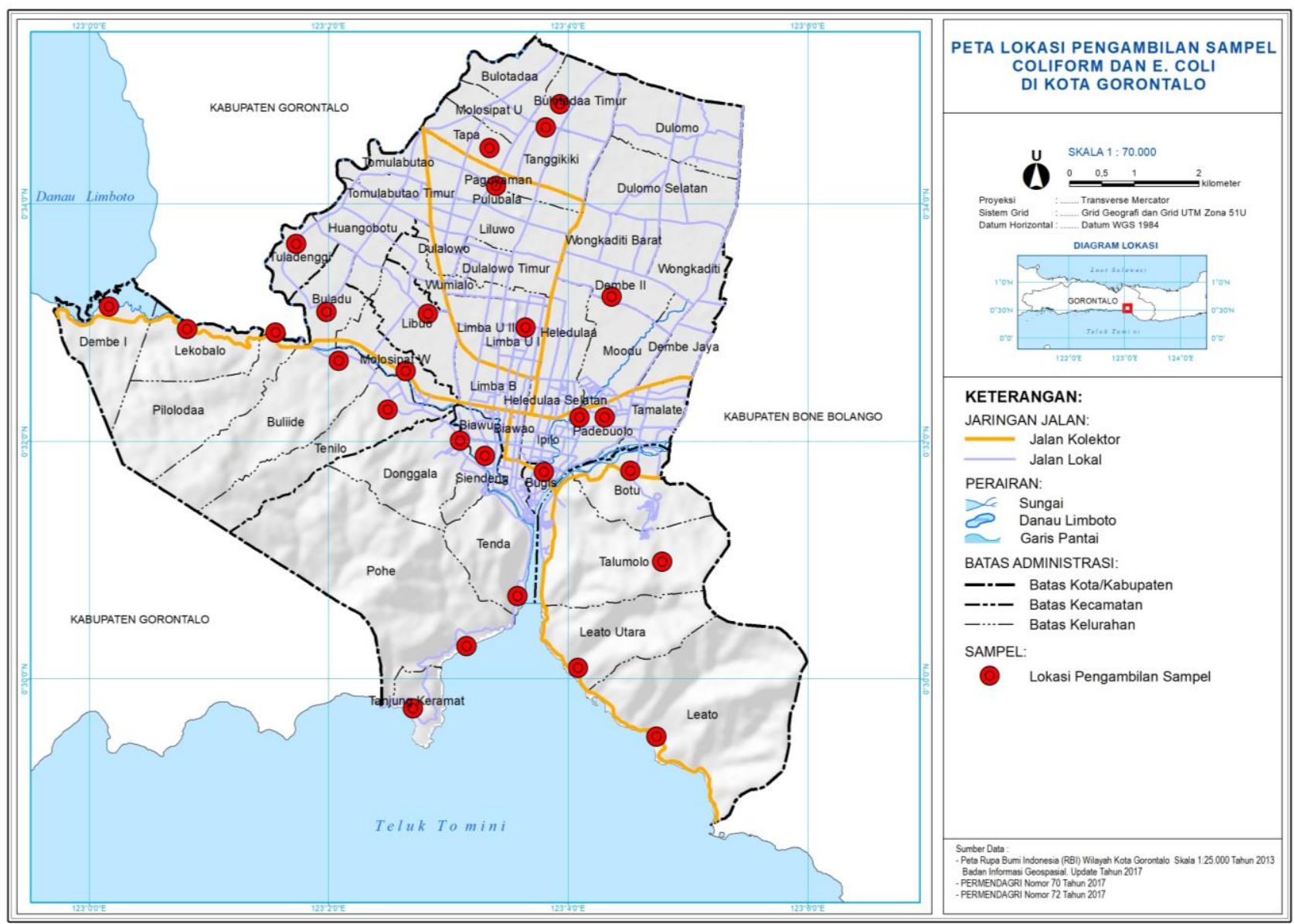

Gambar 1. Peta lokasi penelitian

Kelurahan Dembe Jaya. Kecamatan Kota Timur terdiri atas Kelurahan Padebuolo dan Heledulaan Selatan. Kecamatan Kota Selatan terdiri dari Limba U1. Kecamatan Kota Tengah terdiri dari Kelurahan Liluwo. Kecamatan Sipatana terdiri Kelurahan Tanggikiki, Bulotadaa dan Tapa. Kecamatan Dungingi terdiri atas Kelurahan Tulandenggi dan Libuo. Setiap kelurahan diambil 1 sampel secara acak. Kecamatan Dumbo Raya terdiri atas 5 kelurahan, Kecamatan Hulondalangi terdiri atas 5 kelurahan dan Kecamatan Kota Barat terdiri atas 7 kelurahan. Deskripsi lokasi yang diobservasi adalah kebersihan lokasi, sampah padat sekitar lokasi, adanya kandang ternak dan jarak lokasi sampel dengan septiktank. Total jumlah sampel sebanyak 27. Peta lokasi sampel ditunjukkan pada Gambar 1.

\subsection{Teknik Pengambilan Sampel}

Cara pengambilan dan penanganan sampel merupakan salah satu faktor penting yang menentukan keakuratan hasil pengujian. Dalam penjaminan mutu hasil pengujian menggunakan standar ISO/IEC 17025 , 2005. Standar ISO 17025, 2005, diatur baik kompetensi penguji, petugas pengambil sampel dan teknik pengambilan sampel (Kuswiyanto, 2015). Penelitian ini merupakan penelitian pendahuluan dan bersifat observasi deskriptif. Lokasi pengambilan dipilih secara acak. Sampling dilakukan satu kali. Sampel merupakan data sesaat dan cara pengambilannya dilakukan secara aseptis. Langkah yang harus diperhatikan yaitu sterilisasi alat. Alat yang telah disiapkan disterilisasi ke dalam Autoclave pada temperatur $121^{\circ} \mathrm{C}$ selama 30 menit. Langkah selanjutnya pada saat memasukkan sampel, botol steril segera dibuka dan langsung ditutup. Sampel uji langsung dibawa ke laboratorium untuk dianalisis. Jika sampel tiba di laboratorium sudah melewati jam pemeriksaan atau terdapat antrian pemeriksaan, maka sampel didinginkan pada lemari pendingin. Alat yang digunakan pada laboratorium, berupa cawan petri, tabung reaksi, sendok steril, timbangan analitik, bunsen, autoclave, inkubator, pipet ukur, bluetip, mikropipet, label, vortex, colonycounter, semprotan alkohol, rak tabung reaksi, korek api, tabung durham, kapas dan karet penghisap. Pengambilan sampel pada air sumur menggunakan botol sampel yang sudah disterilisasi. Botol diikat dengan tali dan diberi pemberat. Pada saat pengambilan, botol sampel jangan sampai terkena dinding sumur. Setelah pengambilan sampel, botol dimasukkan ke dalam cold box pada suhu $3^{\circ} \mathrm{C}$ dan langsung dibawa ke laboratorium untuk uji labotaroium. Analisis dilaksanakan di Dinas Kesehatan Kabupaten Gorontalo UPTD Instalasi Laboratorium Kualitas Air. 
Hasil pengolahan data ditampilkan menggunakan tabel dan dibandingkan dengan baku mutu. Hasil analisis laboratorium ditunjukkan dalam peta dan hasil observasi kondisi sekitar ditunjukkan dalam tabel. Kriteria cemaran menggunakan standar PMK 32 Tahun 2017, selanjutnya diinteprestasi.

\subsection{Metode Most Probable Number (MPN)}

Perhitungan coliform maupun E. coli menggunakan metode MPN. Standar MPN yang digunakan yakni SNI 01-2332-1 (2006). MPN merupakan jumlah perkiraan terdekat bakteri. Terdapat tiga langkah pengujian yakni uji dugaan, uji penguat dan uji pelengkap. Uji pertama untuk mengetahui apakah dalam sampel air terdapat bakteri coliform. Jika dalam sampel terdapat coliform, maka dilanjutkan dengan uji kedua yakni apakah bakteri tersebut termasuk coli fecal atau non-fecal. Untuk mengetahui jenis bakteri fecal yang terdapat dalam sampel, maka dilanjutkan dengan uji ketiga. Dalam pengujian menggunakan medium cair pada tabung reaksi. Medium yang digunakan dalam pengujian pertama adalah kaldu laktosa. Pada uji kedua menggunakan Brilliant Green Lactose Bile (BGLB). Pada uji ketiga menggunakan medium Mac Conkey Agar (MCA). Perhitungan dilakukan dengan pendekatan secara statistic. Metode MPN memiliki tingkat kepercayaan 95\%. Pengujian menggunakan jumlah tabung positif dengan menganalisis perubahan medium pada tabung. Perubahan yang ditinjau dapat berupa perubahan warna maupun terbentuknya gelembung gas pada tabung Durham (Kuswiyanto, 2015). Metode perhitungan MPN menggunakan 3 seri pengenceran, yaitu $10^{1}, 10^{2}$ dan $10^{3}$. Pengukuran di laboratorium dengan menggunakan metode MPN. Berdasarkan hasil perubahan tersebut dicari nilai MPN. Untuk menghitung jumlah bakteri menggunakan persamaan 1.

Bakteri = nilai MPN $x 1 /$ pengenceran tengah

Baku mutu yang dijadikan acuan untuk parameter E. coli dan coliform adalah PMK 32 Tahun 2017 lampiran I air untuk keperluan hygiene dan sanitasi, dimana total coliform disyaratkan 50 CPU/ $100 \mathrm{ml}$ dan E. coli $0 \mathrm{CPU} / 100 \mathrm{ml}$.

\section{Hasil dan Pembahasan}

\subsection{Sebaran Spasial Total Coliform dan E. coli}

Air sumur gali sebagai air tanah dangkal, merupakan sumber air bersih bagi masyarakat, baik di kota maupun pedesaan. Hasil analisis total coliform menunjukkan bahwa sebanyak 27 sampel di 27 kelurahan, terdapat 24 sampel berada di atas baku mutu. Hasil analisis pengukuran E. coli, juga menunjukkan hal yang berbeda dimana dari 27 sampel pada berbagai lokasi, terdapat 5 kelurahan melebihi standar mutu yang ditetapkan. Menurut Peraturan Menkes No 32 Tahun 2017, disyaratkan untuk kualitas air hygiene dan sanitasi, parameter total coliform harus berada di bawah 50 MPN dan $E$. coli harus 0 MPN. Dapat disimpulkan hampir semua kualitas air sumur dangkal di Kota Gorontalo sudah tercemar. Hasil analisis ditunjukkan pada Gambar 1.

Jika ditinjau dari sebaran sampel yang berada di Kota Gorontalo, menunjukkan bahwa cenderung air sumur masyarakat yang digunakan sehari-hari tidak layak digunakan. Jika digunakan harus melakukan berbagai pengolahan untuk menurunkan bakteri. Banyak faktor yang mempengaruhi tingginya bakteri di dalam sumur masyarakat. Salah satunya adalah kebersihan di sekitar sumur, keretakan sumur dan jarak antara sumur dan septiktank hanya berkisar 2-9 $\mathrm{m}$. Hasil analisis penelitian parameter coliform dan E Coli ditunjukkan pada Gambar 2.

Jumlah total coliform tertinggi ditandai dengan warna kuning 2400 MPN. Hasil analisis bakteri 2400 MPN sebanyak 20 lokasi (74.07 \%). Sebanyak 2 lokasi yakni Siendeng dan Donggala sebanyak 1600 MPN atau $7.407 \%$ ditandai dengan warna biru pada peta. Satu lokasi yakni Tanjung Kramat sebesar 110 MPN atau 0.91 (\%). Terdapat 3 lokasi atau $11.11 \%$ yang berada di bawah baku mutu yakni Kelurahan Buliide, Buladu dan Buladu. Kelurahan yang sampelnya terendah yakni di Kelurahan Buladu memiliki jumlah bakteri ditandai dengan lokasi berwarna ungu sebanyal $11 \mathrm{MPN}$. Hasil penelitian sebaran coliform yang dilakukan di Kota Gorontalo, sangat tinggi jika dibandingkan dengan hasil analisis jumlah bakteri oleh Hadijah (2017) di Kecamatan Bajeng Kabupaten Gowa. Penelitian Hadijah (2017) hasil coliform berkisar 2 - 59 CPU/100 ml. Jumlah total coliform berada diatas baku mutu, dimana diperbolehkan 50 CPU/100 ml. Hasil analisis di Kelurahan Mataallo Kabupaten Gowa, dari 10 sampel, coliform berkisar 110 - 1600 MPN.

Hasil analisis untuk parameter E. coli menunjukkan bahwa terdapat 5 lokasi yang E. coli nya berada diatas baku mutu yang ditetapkan yakni Heledulaa Selatan, Padebuolo, Limba U1, Bulotadaa dan Tapa (18.51\%). Adanya E. coli pada sumur penduduk menunjukkan bahwa air tersebut tidak layak digunakan. Hasil analisis $E$. coli dalam penelitian ini rendah dibandingkan yang dilakukan oleh 


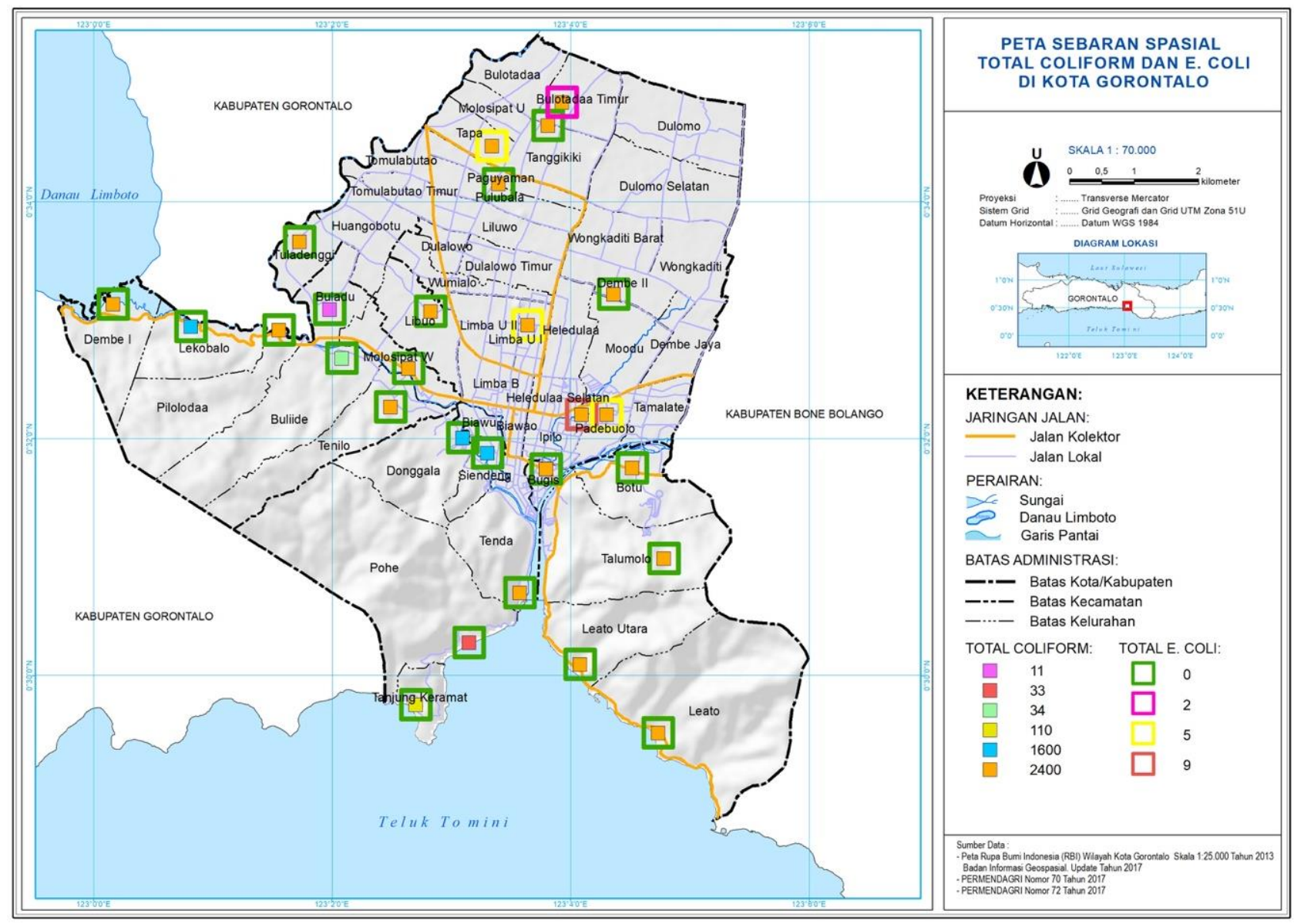

Gambar 2. Hasil sebaran bakteri Coliform dan E. coli di Kota Gorontalo

Amyati (2019). Ditemukan E. coli antara 210-2400 MPN pada 10 sampel sumur gali di Kecamatan Pleret Kabupaten Bantul Daerah Istimewa Yogyakarta menunjukkan (Amyati, 2019).

\subsection{Faktor-Faktor yang Mempengaruhi Adanya Total Coliform dan E. coli pada Air Sumur Dangkal}

Mikroorganisme pathogen menyebabkan gangguan pada kesehatan manusia. Mikroorganisme ini menyebabkan penyakit, yang dikenal dengan penyakit bawaan air. Sumber mikroorganisme pathogen berasal dari tinja manusia dan hewan berdarah panas. Adanya bakteri coliform pada sampel yang diteliti, memberi petunjuk telah terjadi pencemaran tinja manusia (Mulia, 2005). Banyak faktor lingkungan sekitar yang dapat mempengaruhi kondisi karakterirtik kualitas air khususnya parameter mikrobiologi yakni total coliform dan E. coli. Faktor-faktor tersebut dipengaruhi oleh kondisi lingkungan sekitar apakah bersih atau kotor dan juga faktor jarak dapat mempengaruhi kondisi jumlah bakteri di dalam air. Terdapat lima lokasi yang berada di atas baku mutu Padebuolo, Heledulaan Selatan, Limba U1, Bulotadaa dan Tapa. Hasil analisis dilokasi ini berkisar antara 2-9 MPN. Hasil pengamatan kondisi sekitar lokasi sampel dengan hasil analisis mikrobiologi ditunjukkan pada Tabel 1.

Berdasarkan Tabel 1 konsentrasi tertinggi bakteri coliform 2400 MPN pada 20 sumur uji, dengan jarak antara sumur dan septiktank berkisar antara 2 -12 m. Jarak septiktank dengan air sumur gali akan mempengaruhi jumlah bakteri baik coliform maupun E. coli. Indikator jarak dapat mempengaruhi pola sebaran pertumbuhan dan perkembangbiakan mikroorganisme. Jarak sumur sebaiknya minimal $15 \mathrm{~m}$ dari sumber pencemar. Sumur dibuat dengan lokasi lebih tinggi dari sumber pencemaran seperti kakus, kandang ternak, tempat sampah dan lain sebagainya (Amyati, 2019). Penularan Esherichia coli dapat menyebabkan diare akibat terkontaminasi kotoran manusia yang terinfeksi. Pada penelitian ini, ditinjau sebaran lokasinya di Kota Gorontalo, jumlah bakteri coliform sangat tinggi, jika dibandingkan dengan E. coli. Hal ini dapat terjadi, karena coliform merupakan kumpulan dari bakteri, baik pathogen maupun nonpathogen. Bakteri-bakteri nonpathogen dan bukan berasal dari usus dari genus Enterobacter dan beberapa Klebsiella juga menyebabkan uji coliform positif. Pengujian coliform lebih cepat dilakukan karena hanya dilakukan uji penduga. Jika terdapat coliform, maka dilanjutkan dengan uji berikutnya. Jika pada uji dugaan tidak terdapat coliform maka tidak perlu uji penguat dan pelengkap untuk menentukan E. coli (Kuswiyanto, 2016). 
Tabel 1. Faktor-faktor yang mempengaruhi parameter total Coliform dan E. coli

\begin{tabular}{|c|c|c|c|c|c|}
\hline No & Lokasi & $\begin{array}{l}\text { Hasil total } \\
\text { coliform }\end{array}$ & $\begin{array}{l}\text { Hasil } \\
\text { E. coli }\end{array}$ & $\begin{array}{l}\text { Jarak sumur } \\
\text { dengan jamban }\end{array}$ & Kondisi sekitar sumur \\
\hline 1 & Leato Selatan & 2400 & 0 & $12 \mathrm{~m}$ & $\begin{array}{l}\text { Tidak ada sampah } \\
\text { Tidak ada kandang ternak }\end{array}$ \\
\hline 2 & Leato Utara & 2400 & 0 & $5 \mathrm{~m}$ & $\begin{array}{l}\text { Tidak ada sampah } \\
\text { Tidak ada kandang ternak }\end{array}$ \\
\hline 3 & Talumolo & 2400 & 0 & $7 \mathrm{~m}$ & $\begin{array}{l}\text { Tidak ada sampah } \\
\text { Dekat dengan limbah rumah tangga } \pm 3 \mathrm{~m}\end{array}$ \\
\hline 4 & Bugis & 2400 & 0 & $3 \mathrm{~m}$ & $\begin{array}{l}\text { Ada sampah } \\
\text { Dekat kandang ternak } \pm 5 \mathrm{~m}\end{array}$ \\
\hline 5 & Botu & 2400 & 0 & $3 \mathrm{~m}$ & $\begin{array}{l}\text { Tidak ada sampah } \\
\text { Tidak ada kandang ternak }\end{array}$ \\
\hline 6 & Tenda & 2400 & 0 & $3 \mathrm{~m}$ & $\begin{array}{l}\text { Tidak ada sampah } \\
\text { Tidak ada kandang ternak }\end{array}$ \\
\hline 7 & Pohe & 33 & 0 & $7 \mathrm{~m}$ & $\begin{array}{l}\text { Tidak ada sampah } \\
\text { Tidak ada kandang ternak }\end{array}$ \\
\hline 8 & $\begin{array}{l}\text { Tanjung } \\
\text { Kramat }\end{array}$ & 110 & 0 & $3 \mathrm{~m}$ & $\begin{array}{l}\text { Tidak ada sampah } \\
\text { Tidak ada kandang ternak }\end{array}$ \\
\hline 9 & Donggala & 1600 & 0 & $3 \mathrm{~m}$ & $\begin{array}{l}\text { Tidak ada sampah } \\
\text { Tidak ada kandang ternak }\end{array}$ \\
\hline 10 & Siendeng & 1600 & 0 & $8 \mathrm{~m}$ & $\begin{array}{l}\text { Tidak ada sampah } \\
\text { Tidak ada kandang ternak }\end{array}$ \\
\hline 11 & Molosifat W & 2400 & 0 & $4 \mathrm{~m}$ & $\begin{array}{l}\text { Tidak ada sampah } \\
\text { Tidak ada kandang ternak }\end{array}$ \\
\hline 12 & Tenilo & 2400 & 0 & $2 \mathrm{~m}$ & $\begin{array}{l}\text { Tidak ada sampah } \\
\text { Tidak ada kandang ternak }\end{array}$ \\
\hline 13 & Buladu & 11 & 0 & $8 \mathrm{~m}$ & $\begin{array}{l}\text { Tidak ada sampah } \\
\text { Tidak ada kandang ternak }\end{array}$ \\
\hline 14 & Pilolodaa & 2400 & 0 & $4 \mathrm{~m}$ & $\begin{array}{l}\text { Tidak ada sampah } \\
\text { Tidak ada kandang ternak }\end{array}$ \\
\hline 15 & Dembe I & 2400 & 0 & $7 \mathrm{~m}$ & $\begin{array}{l}\text { Tidak ada sampah } \\
\text { Tidak ada kandang ternak }\end{array}$ \\
\hline 16 & Lekobalo & 1600 & 0 & $4 \mathrm{~m}$ & $\begin{array}{l}\text { Tidak ada sampah } \\
\text { Tidak ada kandang ternak }\end{array}$ \\
\hline 17 & Buliide & 34 & 0 & $3 \mathrm{~m}$ & $\begin{array}{l}\text { Tidak ada sampah } \\
\text { Tidak ada kandang ternak }\end{array}$ \\
\hline 18 & Dembe Jaya & 2400 & 0 & $9 \mathrm{~m}$ & Dekat dengan kandang \\
\hline 19 & $\begin{array}{l}\text { Heledulaa } \\
\text { Selatan }\end{array}$ & 2400 & 9 & $5 \mathrm{~m}$ & $\begin{array}{l}\text { Dekat dengan kandang } \\
\text { Banyak sampah }\end{array}$ \\
\hline 20 & Padebuolo & 2400 & 5 & $3 \mathrm{~m}$ & $\begin{array}{l}\text { Ada sampah } \\
\text { Dekat dengan buangan limbah rumah tangga }\end{array}$ \\
\hline 21 & Limba U1 & 2400 & 5 & $2 \mathrm{~m}$ & Kondisi air keruh \\
\hline 22 & Liluwo & 2400 & 0 & $3 \mathrm{~m}$ & $\begin{array}{l}\text { Tidak ada sampah } \\
\text { Tidak ada kandang ternak }\end{array}$ \\
\hline 23 & Tanggikiki & 2400 & 0 & $4 \mathrm{~m}$ & $\begin{array}{l}\text { Tidak ada sampah } \\
\text { Tidak ada kandang ternak }\end{array}$ \\
\hline 24 & Bulotadaa & 2400 & 2 & $3 \mathrm{~m}$ & $\begin{array}{l}\text { Tidak ada sampah } \\
\text { Tidak ada kandang ternak }\end{array}$ \\
\hline 25 & Tapa & 2400 & 5 & $3 \mathrm{~m}$ & Lantai sumur retak/hancur \\
\hline 26 & Tuladenggi & 2400 & 0 & $4 \mathrm{~m}$ & Banyak sampah \\
\hline 27 & Libuo & 2400 & 0 & $8 \mathrm{~m}$ & $\begin{array}{l}\text { Tidak ada sampah } \\
\text { Tidak ada kandang ternak }\end{array}$ \\
\hline
\end{tabular}

Lokasi pengambilan sampel di Kelurahan Tapa menunjukkan bahwa coliform maupun E. coli di atas baku mutu yang ditetapkan. Faktor yang mempengaruhi adalah pada lokasi sumur, terdapat keretakan dan dengan jarak septiktank dan sumur $3 \mathrm{~m}$. Lokasi Kelurahan Bulotadaa, baik coliform maupun E. coli berada di atas standar yang disyaratkan. Kondisi pencemaran lebih dikarenakan jarak septiktank dan sumur yang berdekatan sejauh $3 \mathrm{~m}$. Lokasi Heledulaa Selatan, pencemaran mikrobiologi lebih dipengaruhi oleh adanya kendang ternak dan banyaknya sampah di sekitar sumur gali. Lokasi Limba U1 juga dipengaruhi oleh lokasi yang berdekatan dengan septiktank yang berjarak $2 \mathrm{~m}$. Beberapa 
pensyaratan yang harus diperhatikan dalam membangun sumur gali adalah pergerakan hidup bakteri dalam jarak 3 meter/ hari atau lebih dan kemampuan menembus tanah secara horizontal 1 meter (Enjang, 2000).

Banyak pencemaran yang terjadi secara tidak disengaja seperti kembalinya air buangan ke dalam sumur secara langsung atau melalui tempat bocor dan celah tanah. Misalnya dari kakus ke dalam sumur yang letaknya terlalu dekat, atau karena pipa air bocor menyebabkan adanya hubungan air pipa yang bersih dengan air riul. Pencemaran- pencemaran ini dapat menyebabkan penyakit. Penyakit diare yang penting sebagai penyebab kematian pada bayi yang disebabkan oleh $E$. coli. Frekuensi infeksi pada bayi yang dilahirkan di daerah pemukiman padat dan liar tinggi sekali, berhubung dengan keadaan sanitasi yang pada umumnya buruk (Suriawira, 1996).

Penelitian yang dilakukan oleh Dangiran \& Dharmawan (2020), tentang sebaran diare di Kelurahan Jabungan, banyak ditemukan pada rumah yang memiliki sumur gali. Hasil analisis menunjukkan kualitas bakteriologis air yang tidak memenuhi syarat yaitu $>50 \mathrm{CFU} / 100 \mathrm{ml}$ dengan jarak dengan sumber pencemar $<11 \mathrm{~m}$. Hal ini dapat menimbulkan penyakit. Penyakit bawaan air, dapat menyebar apabila mikroba penyebabnya dapat masuk ke dalam sumber air. Untuk itu perlu melakukan perlindungan atau perawatan terhadap sumur gali masyarakat, sehingga kualitas airnya dapat memenuhi kebutuhannya sehari-hari. Bakteri jenis Esherichia coli dapat menyebabkan diare/disentri (Slamet, 1994). Jika dibanding penelitian ini, maka hasil observasi menunjukkan jarak antara sumur dan septiktank adalah 2-9 meter, sehingga dapat terjadi rembesan dari septiktank ke sumur gali terdekat dan mencemarinya. Hal ini harus diwaspadai oleh masyarakat di Kota Gorontalo, dan harus segera dilakukan pencegahan secepatnya sehingga resiko terkena diare dapat berkurang.

Diare merupakan penyakit dengan urutan 5 dari 10 besar penyakit di Provinsi Gorontalo (BPS, 2019). Jumlah penderita tercatat 19.654 jiwa. Faktor penyebabnya adalah keadaan gizi, hygiene dan sanitasi, sosial, budaya, kepadatan penduduk dan sisial ekonomi dapat mempengaruhi tingginya penyakit diare. Menurut WHO, penyebab diare adalah Rotavirus dan Escherichia coli. Bakteri tersebut merupakan agen penyakit. Faktor lingkungan yang mempengaruhi antara lain hygiene sanitasi, kecukupan sarana air bersih dan air minum serta kebersihan. Air sebagai media penularan penyakit dapat menurunkan kesehatan masyarakat. Salah satu penyebabnya adalah coliform (Dangiran \& Dharmawan, 2020).

Berdasarkan uraian di atas perlu diantisipasi oleh masyarakat untuk selektif menggunakan air dan untuk sumber air baku air minum agar dimasak terlebih dahulu. Jamban yang sehat, adalah jamban yang selalu dibersihkan setelah digunakan. Pengelolaan tinja dapat berupa on-site atau community on-site. Pengelolaan on-site, tinja ditampung dan selanjutnya diolah di lokasi sekitar. Pengelolaan tinja off-site, tinja dialirkan ke tempat pengolahan lanjutan. Pengelolaan system community on-site, pengelolaan tinja dilakukan secara kolektif dengan mempertimbangkan, jamban tidak akan mencemari air tanah disekitarnya (Mulia, 2005).

\section{Kesimpulan}

Hasil analisis menunjukkan bahwa sebaran total coliform di Kota Gorontalo, dari 27 sampel terdapat sebanyak 24 lokasi sampel berada di atas baku mutu yang diizinkan dan 3 sampel lainnya berada di bawah baku mutu PMK 32 Tahun 2017. Khusus untuk parameter E. coli dari total 27 sampel terdapat 5 lokasi berada di atas baku mutu yang ditetapkan. Hasil analisis menunjukkan bahwa konsentrasi tertinggi bakteri coliform $2400 \mathrm{MPN}$. Hasil tersebut terdapat pada 20 sampel sumur dengan jarak antara sumur dan septiktank berkisar antara 2-12 m. Lokasi pengambilan sampel Kelurahan Tapa menunjukkan bahwa coliform maupun $E$. coli di atas baku mutu yang ditetapkan. Faktor yang mempengaruhi adalah pada lokasi sumur, terdapat keretakan dengan jarak septiktank dan sumur sejauh $3 \mathrm{~m}$. Lokasi Kelurahan Bulotadaa, baik coliform maupun E. coli juga berada di atas baku mutu yang ditetapkan. Kondisi pencemaran lebih disebabkan karena jarak septiktank dan sumur yang berdekatan sejauh $3 \mathrm{~m}$. Lokasi kelurahan Heledulaa Selatan, pencemaran mikrobiologi lebih dipengaruhi oleh adanya kendang ternak dan banyaknya sampah di sekitar sumur gali. Lokasi Limba U1 juga dipengaruhi oleh lokasi yang berdekatan dengan septiktank yang berjarak $2 \mathrm{~m}$. Perlu penelitian lanjutan untuk mencari pemodelan sebaran spasial dan temporal untuk mengetahui pengaruh coliform dan E. coli dan pengaruhnya terhadap kesehatan masyarakat. 


\section{Ucapan Terima Kasih}

Ucapan terima kasih kepada Rektor, Dekan dan Kepala Lembaga Penelitian yang telah membantu terselesainya penelitian ini. Khusus ucapan terima kasih kepada semua penulis buku maupun jurnal yang dijadikan sumber ilmu pengetahuan dalam melancarkan kajian hasil penelitian ini.

\section{Referensi}

Amyati, A., (2019). Identifikasi Bakteri Esherichia Pada Air Sumur Gali. Jurnal Ilmiah Ilmu Kesehatan, 4 (2), 88-94.

Awuy, S. C. Sumampouw, O.J. \& Boky H.B. (2018). Kandungan Escherichia Coli Pada Air Sumur Gali dan Jarak Sumur Septic Tank di Kelurahan Rap-Rap Kabupaten Minahasa Utara Tahun 2018. E. Jurnal Kesmas. 7 (4), 1-6.

[BPS] Badan Pusat Statistik, (2019). Data Sensus Jumlah Penduduk Menurut Kabupaten/Kota di Provinsi Gorontalo. Gorontalo: BPS Provinsi Gorontalo.

Cornelissen, C. N., Fisher, B. D. \& Harvey, R. A., (2015). Ilustrasi Berwarna Mikrobiologi. Ketiga ed. Tangerang Selatan: Binarupa Aksara.

Dangiran, H. L. \& Dharmawan, Y., (2020). Analisis Spasial Kejadian Diare Dengan Keberadaan Sumur Gali di Kelurahan Jabungan Kota Surakarta. Jurnal Kesehatan Lingkungan Indonesia, 19 (1), 68-75.

Enjang. (2000). Ilmu Kesehatan Masyarakat. Bandung: Citra Aditya.

Galanis, E. et al., (2014). The Association Between Campylobacteriosis, Agriculture and Drinking Water : A Case-Case Study in Region of British Colombia, Canada, 2005-2009. Epidemiology \& Infection, 142 (10), 2075-2084.

Hadijah, S., (2017). Analisis MPN (Most Probable Number) Coliform Pada Air Sumur Gali Penduduk Yang Bermukim di Sekitar Kanal Kelurahan Mataallo Kecamatan Bajeng Kabupaten Gowa. Media Analis Kesehatan, 8 (2), 83-90.

Invik, J., Barkema, H. W., Massolo, A. \& Checkley, S., (2017). Total Coliform and Escherichia Coli Contamination in Rural Well Water Analysis for Passive Surveillance. Water \& Health, 15 (5), 729-740.

Irdawati, I., Fifendy M. \& Kurniati, D. (2012). Uji Bakteriologis Air Sumur Pemukiman Penduduk di Sekitar Tempat Pembuangan Akhir Sampah. Jurnal Saintek. 4 (2), 136-140.

Kuswiyanto, (2015). Bakteriologi 1. - ed. Jakarta: Buku Kedokteran EGC.

Kuswiyanto, (2016). Bakteriologi 2. Jakarta: Buku Kedokteran EGC.

Mulia, R. M., (2005). Kesehatan Lingkungan. Pertama ed. Jakarta Barat: Graha Ilmu.

Peraturan Menteri Kesehatan., (2017). Tentang Standar Baku Mutu Kesehatan Lingkungan dan Persyaratan Kesehatan Air Untuk Keperluan Higiene Sanitasi, Kolam Renang, Solus Per Aqua, dan Pemandian Umum, Jakarta. Kementrian Republik Indonesia Balai Besar Teknik Kesehatan Lingkungan dan Pengendalian Penyakit Banjarbaru.

Putra, C. M. M. (2018). Kualitas Fisik dan Coliform Air Sumur di Dusun Nanas Kabupaten Kediri Pasca Fenomena Alam Sumur Ambles. Jurnal Kesehatan Lingkungan. 10 (4), 360-367.

Putri, A. M. \& Kurnia, P. (2018). Identifikasi Keberadaan Bakteri Coliform dan Total Mikroba Dalam Es Dung-Dung di Sekitar Kampus Universitas Muhammadiyah Surakarta. Media Giji Indonesia, 13(1), 41-48.

Slamet, J. S. (1994). Kesehatan Lingkungan. Bandung: Gadjah Mada University Press.

SNI 012332.1 (2006). Cara Uji Mikrobiologi Bagian 1 Penentuan Coliform dan Esherichia coli pada Produk Perikanan.

Suriawira, U., (1996). Mikrobiologi Air dan Dasar-Dasar Pengolahan Air Buangan Secara Biologis. Pertama ed. Bandung: Alummi. 